\title{
AMN 082, an Agonist of mGluR7, Exhibits Mixed Anti- and Proconvulsant Effects in Developing Rats
}

\author{
P. MARE ̌̌ \\ Department of Developmental Epileptology, Institute of Physiology, Academy of Sciences of the \\ Czech Republic, Charles University, Second Medical Faculty, Department of Rehabilitation and \\ Exercise Medicine, Prague, Czech Republic
}

Received August 31, 2008

Accepted October 2, 2008

\begin{abstract}
Summary
Metabotropic glutamate receptors (mGluRs) represent a potential therapeutic target. Possible anticonvulsant action of AMN 082, an agonist of mGluR7 subtype, was studied in immature rats using pentylenetetrazol (PTZ)-induced seizures as a model. Five age groups of rats (7-, 12-, 18-, 25-day-old and adult animals) were pretreated with AMN 082 in doses of $0.5,1,2$, and $5 \mathrm{mg} / \mathrm{kg}$ i.p. and $30 \mathrm{~min}$ later PTZ was administered (100 mg/kg s.c.). Controls received saline instead of the agonist. AMN 082 did not exhibit clear anticonvulsant action with the exception of suppression of the tonic phase of generalized tonic-clonic seizures (GTCS) in 12-day-old rats. Shorter latencies of GTCS after AMN 082 pretreatment indicate a proconvulsant action. Involuntary movements (mostly tremor) appeared after AMN 082 before PTZ administration, therefore we performed another experimental series with AMN 082 only $(1,2,5$, and $10 \mathrm{mg} / \mathrm{kg}$ i.p.). During 60-min observation period tremor appeared in all age groups; sensitivity to this action decreased with age from the $2 \mathrm{mg} / \mathrm{kg}$ dose in 7- and 12-day-old rats to the $10 \mathrm{mg} / \mathrm{kg}$ dose in adult rats. Mixed anti- and proconvulsant actions of AMN 082 together with unwanted motor effects makes clinical use of this drug highly improbable.
\end{abstract}

\section{Key words}

Seizures • Rat • Ontogeny • mGluR7 • Unwanted motor effects

\section{Corresponding author}

P. Mareš, Institute of Physiology, Academy of Sciences of the Czech Republic, Vídeňská 1083, CZ-14220 Prague 4, Czech Republic. E-mail: maresp@biomed.cas.cz
Glutamate as the main excitatory transmitter in the brain plays a key role in generation of epileptic seizures and antagonists of ionotropic glutamate receptors exhibit marked anticonvulsant action. Unfortunately, they also exhibit very strong adverse effects (especially antagonists of N-methyl-D-aspartate type of receptors) in adult and immature rodents (Chapman 1991, Mareš et al. 2004). Attention was shifted to drugs influencing metabotropic glutamate receptors (for review see Alexander and Godwin 2006). Metabotropic glutamate receptors are divided into three groups formed by 8 subtypes (Conn and Pin 1997). Among the drugs active at individual subtypes of metabotropic glutamate receptors (mGluRs) agonists or drugs positively modulating group III of mGluRs (consisting of mGluR4, mGluR6, mGluR7 and mGluR8) may be interesting because these receptors are primarily localized presynaptically also as autoreceptors on glutamatergic nerve endings (Cartmell and Schoepp 2000). Activation of these receptors can decrease release of glutamate and this action might counteract epileptic hyperactivity. In addition, anxiolytic and antidepressant actions of agonists of group III mGluR were described (Palucha and Pilc 2007). To have an antiepileptic drug with marked anxiolytic and antidepressant properties may be very useful for treatment of epilepsies because epileptic patients have frequently psychic problems connected with their illness. Majority of epilepsies has origin in infancy and childhood (Hauser et al. 1991), therefore studies of potential antiepileptic drugs in immature animals are necessary. There are no developmental data outside our 
laboratory on anticonvulsant action of drugs influencing mGluRs. Previously, we demonstrated anticonvulsant action of antagonists of group I of mGluRs (Mareš and Mikulecká 2004, Lojková and Mareš 2005) and their anxiolytic action (Mikulecká and Mareš - submitted) in immature rats. To study a role of group III of mGluRs in epileptic seizures we started experiments with mGluR7 agonist AMN 082. This drug, which is commercially available, was demonstrated to cross blood-brain barrier if administered systemically (Mitsukawa et al. 2005). Pentylenetetrazol-induced motor seizures were chosen for the initial study because models of two types of convulsive seizures can be tested in one experiment and we have data on the effects of other drugs influencing glutamate receptors (Mareš and Mikulecká 2004, Mareš et al. 2004).

Experiments performed on 7-, 12-, 18-, 25-dayold and adult male Wistar rats were approved by Animal Care and Use Committee of the Institute of Physiology to be in agreement with Animal Protection Law of the Czech Republic and with ECC directives 86/609/EEC.

Rats were pretreated with AMN 082 (N,N'dibenzhydryl-ethane-1,2-diamine dihydrochloride, Ascent Scientific, UK) in intraperitoneal doses of $0.5,1$, 2, and $5 \mathrm{mg} / \mathrm{kg}$ and $30 \mathrm{~min}$ later Pentylenetetrazol (PTZ, Sigma Aldrich Czech Republic) was administered subcutaneously at a dose of $100 \mathrm{mg} / \mathrm{kg}$. AMN 082 was replaced by saline in control rats. Animals were then observed in isolation for $30 \mathrm{~min}$, body temperature of the three youngest groups was maintained by means of a pad heated electrically at $34{ }^{\circ} \mathrm{C}$. Incidence, pattern and latency of seizures were recorded and seizure severity was quantified by a 5-point scale (Pohl and Mareš 1987). Latencies and seizure severity were statistically evaluated by means of ANOVA with subsequent pairwise comparison using Holm-Sidak test, incidence of seizures by Fisher exact test (SigmaStat SYSTAT). Statistical significance was accepted if $\mathrm{p}<0.05$. Details of evaluation were the same as described previously (Mareš et al. 2006).

Higher doses of AMN 082 led in some animals to involuntary movements (tremor, jerks of forelimbs), therefore we added another series of animals injected only with $\mathrm{AMN} 082$ (1, 2, 5 and $10 \mathrm{mg} / \mathrm{kg}$ i.p.) and observed in isolation for $40 \mathrm{~min}$. Incidence of involuntary movements was registered.

Incidence of minimal seizures was significantly decreased only by the $5 \mathrm{mg} / \mathrm{kg}$ dose in 18-day-old rats. Outlined changes in older animals $(50 \%$ incidence of
Incidence of generalized seizures - AMN 082

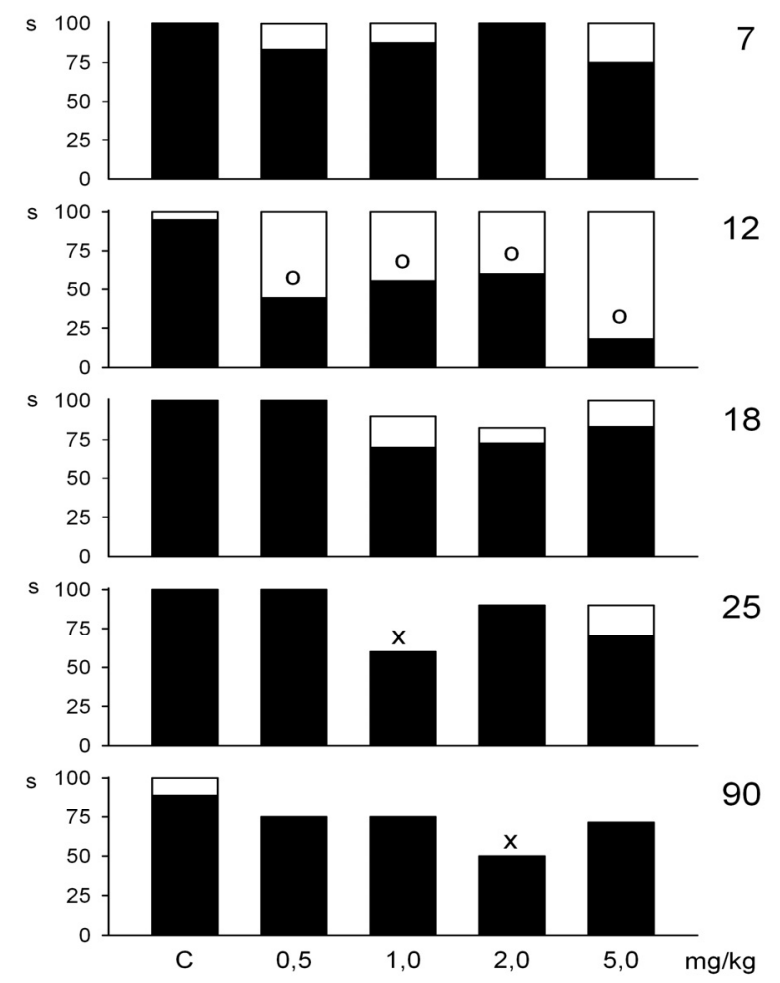

Fig. 1. Incidence of generalized tonic-clonic seizures (black parts of columns) and generalized clonic seizures (white parts of columns) in rat 7, 12, 18, 25 and 90 days old (from top to bottom). Abscissae: doses of AMN 082, C means control animals; ordinates: percentage of rats exhibiting seizures. $X$ denotes significant decrease of incidence of generalized seizures; 0 significant decrease of incidence of the tonic phase.

minimal seizures after the $5 \mathrm{mg} / \mathrm{kg}$ dose in 25-day-old rats and after the $2 \mathrm{mg} / \mathrm{kg}$ dose in adult animals) did not reach the level of significance. Effects on generalized tonic-clonic seizures varied according to the age of rats (Fig. 1). Whereas effects in 7- and 18-day-old rats were negligible, 12-day-old animals exhibited significant suppression of the tonic phase by all four applied doses. AMN 082 suppressed only exceptionally generalized tonic-clonic seizures in 25-day-old and adult rats.

Severity of seizures was significantly decreased only in 12-day-old rats by the $0.5 \mathrm{mg} / \mathrm{kg}$ and $5 \mathrm{mg} / \mathrm{kg}$ doses due to marked suppression of the tonic phase of GTCS. Tendencies in all other age and dose groups stayed below the level of significance.

Latencies of minimal seizures were prolonged only by the highest dose of AMN 082 in 25-day-old rats from $187 \pm 14$ in controls to $351 \pm 54$ s. On the contrary, the same dose of AMN 082 significantly shortened these latencies in 18-day-old and adult animals (from 126 \pm 10 to $67 \pm 9 \mathrm{~s}$ and from $513 \pm 63$ to $230 \pm 51 \mathrm{~s}$, respectively). 
Only proconvulsant effects on latencies of generalized tonic-clonic seizures were observed in four out of five age groups, only 25-day-old rats exhibited a tendency to prolongation of latencies. Again, the $5 \mathrm{mg} / \mathrm{kg}$ dose of AMN 082 significantly decreased the latencies of GTCS in all four above mentioned groups (from $287 \pm 20$ to $199 \pm 16 \mathrm{~s}$, from $242 \pm 26$ to $126 \pm 20 \mathrm{~s}$, from $186 \pm 15$ to $123 \pm 14 \mathrm{~s}$ and from $1008 \pm 123$ to $441 \pm 59 \mathrm{~s}$ in $7-, 12-, 18$ day-old and adult rats, respectively). In addition, the $2 \mathrm{mg} / \mathrm{kg}$ dose was similarly efficient in 18-day-old animals and the dose of $0.5 \mathrm{mg} / \mathrm{kg}$ in adult rats. Other doses either did not change latencies at all or the observed tendencies did not reach the level of statistical significance.

AMN 082 alone was able to elicit involuntary movements mostly represented by tremor of head and forelimb muscles. Movements of forepaws can be described as shuffling or paddling; they never had a locomotor effect. They were observed in all age groups with latencies between 15 and $20 \mathrm{~min}$ after the administration of AMN 082 and lasted till the end of observation (40 min). Effective doses varied according to the age of animals. The two youngest groups were highly sensitive with exactly the same results - even the dose of $2 \mathrm{mg} / \mathrm{kg}$ elicited these movements in 3 out of 8 rats, the $5 \mathrm{mg} / \mathrm{kg}$ dose in 7 out of 8 and the highest dose $(10 \mathrm{mg} / \mathrm{kg})$ in all 8 rats. Only 2 out of 8 rats aged 18 days exhibited a few short periods of tremor after the $2 \mathrm{mg} / \mathrm{kg}$ dose; long-lasting involuntary movements were observed in 6 out of 8 rats with the dose of $5 \mathrm{mg} / \mathrm{kg}$ and in all animals with the $10 \mathrm{mg} / \mathrm{kg}$ dose. The $2 \mathrm{mg} / \mathrm{kg}$ dose never elicited tremor in 25-day-old and adult rats. The $5 \mathrm{mg} / \mathrm{kg}$ and $10 \mathrm{mg} / \mathrm{kg}$ doses were partly active in 25-day-old rats because 3 and 6 out of 8 animals, respectively, exhibited tremor. Adult rats exhibited tremor only exceptionally but especially the $10 \mathrm{mg} / \mathrm{kg}$ dose led to the appearance of automatisms - face washing and intense sniffing.

In contrast to antagonists of mGluR5 (Mareš and Mikulecká 2004, Lojková and Mareš 2005) anticonvulsant action of AMN 082 found in our experiments was moderate and developmentally irregular. The only marked effect - suppression of the tonic phase of generalized tonic-clonic seizures in 12-day-old rats even with low doses of AMN 082 - is in agreement with highest expression of mGluR7 in immature rat brain demonstrated for mRNA (Kinzie et al. 1995) and with a specific mGluR7a antibody with a maximum at postnatal day 14 (Bradley et al. 1998). Absence of this effect in 7and 18-day-old rat was surprising because the difference in mGluR7 immunoreactivity in neocortex, hippocampus and thalamus between 14-, 7- and 21-day-old rats are small (Bradley et al. 1998). Developmental profile of mGluR7 in the brainstem (pons/medulla), i.e. the structure which is generating generalized tonic-clonic seizures (Browning and Nelson 1986), does also not fit with our findings - the level is high in 7-day-old rats and sharply decreases with maturation (Bradley et al. 1998). At present we are not able to explain isolated findings of anticonvulsant action (suppression of GTCS) in 25-dayold and adult rats.

Proconvulsant action of AMN 082 demonstrated mainly as shorter latencies of seizures in all age groups with the exception of 25-day-old rats may reflect activation of mGluR7 heteroreceptors on terminals of GABAergic neurons. The role of these heteroreceptors in GABA release was suggested by Lafon-Cazal et al. (1999) in neuron-rich striatal cultures.

Doses, which induced involuntary movements (tremor and forelimb shuffling), increases with age. This is in agreement with developmental decrease of mGluR7a immunopositivity in two brain structures important for motor control - cerebellum, where the decrease is steep, and striatum with only moderate decrease (Bradley et al. 1998). Decrease in doses eliciting tremor is also moderate, therefore striatum should be a primary target for future analysis of this phenomenon.

We did not find an expected clear anticonvulsant effect. On the contrary, our data deny possible use of AMN 082 as an anticonvulsant. Unwanted motor effects must be carefully analyzed before introduction of this drug or its congeners into clinical use.

\section{Conflict of Interest}

There is no conflict of interest.

\section{Acknowledgements}

This study was supported by a grant No. 305/06/1188 of the Grant Agency of the Czech Republic and by a research project No. AV0Z 50110905 of the Academy of Sciences of the Czech Republic. 


\section{References}

ALEXANDER GM, GODWIN DW: Metabotropic glutamate receptors as a strategic target for the treatment of epilepsy. Epilepsy Res 71: 1-22, 2006.

BRADLEY SR, REES HD, YI H, LEVEY AI, CONN PJ: Distribution and developmental regulation of metabotropic glutamate receptor 7a in rat brain. J Neurochem 71: 636-645, 1998.

BROWNING RA, NELSON DK: Modification of electroshock and pentylenetetrazol seizure patterns in rats after precollicular transections. Exp Neurol 93: 546-556, 1986.

CARTMELL J, SCHOEPP DD: Regulation of neurotransmitter release by metabotropic glutamate receptors. J Neurochem 75: 889-907, 2000.

CHAPMAN AG: Excitatory amino acid antagonists and therapy of epilepsy. In: Excitatory Amino Acid Antagonists. MELDRUM BS (ed), Blackwell, London, 1991, pp 265-286.

CONN PJ, PIN J-P: Pharmacology and functions of metabotropic glutamate receptors. Annu Rev Pharmacol Toxicol 37: 207-237, 1997.

HAUSER WA, ANNEGERS JF, KURLAND LT: Prevalence of epilepsy in Rochester, Minnesota: 1940-1980. Epilepsia 32: 429-445, 1991.

KINZIE JM, SAUGSTAD JA, WESTBROOK GL, SEGERSON TP: Distribution of metabotropic glutamate receptor 7 messenger RNA in the developing and adult rat brain. Neuroscience 69: 167-176, 1995.

LAFON-CAZAL M, VIENNOIS G, KUHN R, MALITSCHEK B, PIN J-P, SHIGEMOTO R, BOCKAERT J: mGluR7-like receptor and GABA receptor activation enhance neurotoxic effects of N-methyl-D-aspartate in cultured mouse striatal GABAergic neurones. Neuropharmacology 38: 1631-1640, 1999.

LOJKOVÁ D, MAREŠ P: Anticonvulsant action of an antagonist of metabotropic glutamate receptors mGluR5 MPEP in immature rats. Neuropharmacology 49: 219-229, 2005.

MAREŠ P, MIKULECKÁ A: MPEP, an antagonist of metabotropic glutamate receptors, exhibits anticonvulsant action in immature rats without a serious impairment of motor performance. Epilepsy Res 60: 17-26, 2004.

MAREŠ P, FOLBERGROVÁ J, KUBOVÁ H: Excitatory aminoacids and epileptic seizures in immature brain. Physiol Res 53 (Suppl 1): S115-S124, 2004.

MAREŠ P, HAUGVICOVÁ R, KASAL A: Action of two neuroactive steroids against motor seizures induced by pentetrazol in rats during ontogeny. Physiol Res 55: 437-444, 2006.

MITSUKAWA K, YAMAMOTO R, OFNER S, NOZULAK J, PESCOTT O, LUKIC S, STOEHR N, MOMBEREAU C, KUHN R, MCALLISTER KH, VAN DER PUTTEN H, CRYAN JF, FLOR PJ: A selective metabotropic glutamate receptor 7 agonist: Activation of receptor signaling via an allosteric site modulates stress parameters in vivo. Proc Nat Acad Sci USA 102: 18712-18717, 2005.

PALUCHA A, PILC A: Metabotropic glutamate receptor ligands as possible anxiolytic and antidepressant drugs. Pharmacol Ther 115: 116-147, 2007.

POHL M, MAREŠ P: Flunarizine influences metrazol-induced seizures in developing rats. Epilepsy Res 1: 302-305, 1987. 